\title{
THE CONTRIBUTION OF BISHOPS FROM THE COMMUNIST STATES TO THE DOCTRINE OF THE SECOND VATICAN COUNCIL IN RESPECT OF CHURCH-STATE RELATIONS
}

The efforts of the Second Vatican Council were intended to answer the question posed by the Church: Eccleasiae, quid dicis de te ipsa? ${ }^{1}$ This research also encompasses the issue of Church-State relations, which was addressed by Vatican II in three aspects. In their examination of those relations, the Council Fathers strove to elaborate their response to the central question developed in the light of the Magisterium concerning the Church, which was presented as (a) a hierarchically structured institution, finally moulded by the dogmatic constitution on the Church Lumen gentium; ${ }^{2}$ (b) an institution uniting Christians living worldwide along with members of other religions and people of no confession a fact which formed the content of the declaration on religious freedom Dignitatis humanae $;^{3}$ (c) an institution functioning in the world, in concrete circumstances of place and time, whose members are both citizens of a state - an issue addressed by the pastoral constitution on the Church in the modern world Gaudium et spes. ${ }^{4}$

Dr. Anna SŁowikowska - Assistant Professor at the Department of Public and Constitutional Church Law, Institute of Canon Law, Faculty of Law, Canon Law and Administration of the John Paul II Catholic University of Lublin, ul. Spokojna 1, 20-74 Lublin, Poland; e-mail: anna.slowikowska@, kul.pl; https://orcid.org/0000-0002-9002-166X

Dr AnNa SŁowIKowSKA - adiunkt w Katedrze Kościelnego Prawa Publicznego i Konstytucyjnego, Instytut Prawa Kanonicznego, Wydział Prawa, Prawa Kanonicznego i Administracji, Katolicki Uniwersytet Lubelski Jana Pawła II, ul. Spokojna 1, 20-74 Lublin; e-mail: anna.slowikowska@kul.pl; https://orcid.org/0000-0002-9002-166X

${ }^{1}$ Translated into English as "O Church, what do you say about yourself?" [WoJTYŁa 2002, 12].

${ }^{2}$ Sacrosanctum Concilium Oecumenicum Vaticanum II, Constitutio dogmatica de Ecclesia Lumen gentium (21.11.1964), AAS 57 (1965), pp. 5-67.

${ }^{3}$ IDEM, Declaratio de libertate religiosa Dignitatis humanae (7.12.1965), AAS 58 (1966), pp. 929-946.

${ }^{4}$ IDEM, Constitutio pastoralis de Ecclesia in mundo huius temporis Gaudium et spes (7.12.1965), AAS 58 (1966), pp. 1025-1115. 
Taking the three subject areas into consideration, the aim of the article will be to present the Church-State relations as they were conceived by the Second Vatican Council during the preparatory stage when the said documents were being drafted. This aim will be achieved by analysing the speeches and written remarks, or the so-called animadversiones, formulated by the Council Fathers who represented particular Churches located in the territories of the states of the so-called communist bloc. The fact that the Author chose only speeches and remarks submitted during the Council by the representatives of church authorities in those countries is not random. It was there that the functioning of church communities was immensely difficult given the presence of totalitarian regimes. Therefore, it will be crucial to demonstrate the contribution of those bishops to the teaching of the Council. Through their experience they would reveal to all bishops worldwide the real obstacles the Church had to overcome. Therefore, given our research problem, the analysis should also cover the viewpoint presented by Cardinal Paul Poupard. Evaluating the participation of Archbishop Karol Wojtyła in Vatican II, this official of the Roman Curia said: "He became a conspicuous participant because he was practically the only bishop from the communist countries who dared to speak out" [POUPARD 2005, 99]. Since the presented study will examine the involvement of individual church hierarchs in the sessions, including those of Archbishop Wojtyła, we should pose the following question: is Cardinal Poupard's opinion permissible in the context of the contribution of bishops of the communist states to the teaching of the Second Vatican Council with respect to Church-State relations?

\section{THE POLITICAL CONTEXT OF CHURCH-STATE RELATIONS ON THE EVE OF VATICAN II}

A communist state is one founded on the Marxist-Leninist ideology and subject to the dictatorship of a communist party. The first state of this kind was the Soviet Union, established in the wake of the October Revolution or 1917. After World War II, this model was imposed on the states of Central-Eastern Europe, which formed a bloc of communist states as a result of the arrangements arrived at during the proceedings of the Jalta Agreement [KRUKOWSKi 2000, 74]. Yet, while the Jalta sessions were in progress, J. Goebbels declared on February 25, 1945: "If the German people lay down their weapons, the Soviets, according to the agreement between Roosevelt, Churchill, and Stalin, would occupy all of East and Southeast Europe along with the greater part of the Reich. An iron curtain would fall over this enormous territory controlled by the Soviet Union, behind 
which nations would be slaughtered" [GoEbBELS 2000]..$^{5}$ And so it happened. Militant atheism would wage war against the whole humanity, which would not surrender to the ideology of communism. The attitude of the authorities towards the freedom of conscience and religion and to religious organisations hinged on ideological precepts and the policy of the USSR. Any manifestations of religion were treated as an expression of ignorance and backwardness. Virtually all traces of religious life were eradicated from the social life of the USSR. War with the Church and religion was part of the programme of state authorities also in other Communist states [MiszTaL 2003, 128].

Despite the dramatism of the political situation, Pope John XXIII decided to convoke the Second Vatican Council. The goal of this assembly was to conduct the so-called aggiornamento, i.e. bringing up to date, renewal, and adjustment of the activity of the Church to the changes which had taken place in the contemporary world.

Of the total of 3,058 participants, ${ }^{6} 198$ bishops from the Communist Bloc took part, ${ }^{7}$ including: 1 from Belorus, ${ }^{8} 1$ from Bulgaria, ${ }^{9} 61$ from China, ${ }^{10} 5$ from

\footnotetext{
${ }^{5}$ The term "iron curtain" was mistakenly ascribed to W. Churchill, who on March 5, 1946, in his speech entitled The Sinews of Peace, merely paraphrased Goebbels' words by saying: "From Stettin in the Baltic to Trieste in the Adriatic, an «iron curtain» has descended across the Continent. Behind that line lie all the capitals of the ancient states of Central and Eastern Europe. Warsaw, Berlin, Prague, Vienna, Budapest, Belgrade, Bucharest and Sofia, all these famous cities and the populations around them lie in what I must call the Soviet sphere, and all are subject in one form or another, not only to Soviet influence but to a very high and, in many cases, increasing measure of control from Moscow" [CHURCHILL 1974, 7285-293].

${ }^{6}$ Data collected by the General Secretariat of the Council, retrieved from the table subtitled The Fathers present at Vatican II, in MeLLONI 2015, 85.

${ }^{7}$ The list does not include bishops from GDR.

${ }^{8}$ Sipović Ceslao.

${ }^{9}$ Kurteff Kyril Stefan.

${ }^{10}$ Aramburu Urquiola Zenon, Bassi Assuero Teofano, Bianchi Lorenzo, Boisguérin René-Desiré-Romain, Brellinger Leopold, Capozi Domenico Luca, Caprio Giuseppe, Ceól Orazio Ferruccio, Chang Tso-huan Vito, Cheng Tien-Siang Joseph, Civelli Mario, Cleary Patric, Côté Philip, Derouineau Alexandre-Joseph-Chrles, Desperben Dominic, Donaghy Frederic Anthony, Fahy Eugene, Ferroni Alfonso Maria Corrado, Grimm Peter Gratian, Häring Edgar Anton, Hintringer da Losenstein Isidor Hermenegild, Hugentobler Paul, König Inigo Maximilian, Kowalski Casimir Rembert, Kramer Francis Gerard Constantin, Krause Ignacy, Kurz Blasius Sigibald, Labrador Fraile Theodore, Lacchio Secondino Petronio, Lacoste Lucien Bernard, Larrañaga Lasa Ignacio Gregorio, Lesinski Johann Werner, Lokuang Stanislaus, Maggi Giuseppe, Maleddu Pietro, Massa Pietro, Melendro y Gutiérrez Federico, Mignani Gaetano, Morelti Pietro, Niu Hui-ching Thomas, O'Gara Cutgert Martin, Olbert Augustin, Oste Joseph Julian, Pasini Ferdinando Fulgencio, Pessers Quintinus, Pinault Henri-Marie-Ernest-Désiré, Pinger Henry Ambrose, Quint Edward Gabriel, Quintanilla Manzanares del Rosario Arturo, Romaniello John Angel, Schu Theodore, Tien Kenh-hsin
} 
Czechoslovakia, ${ }^{11} 25$ from Yugoslavia, ${ }^{12} 3$ from Laos, ${ }^{13} 1$ from Lithuania, ${ }^{14} 3$ from Latvia, ${ }^{15} 3$ from Korea ${ }^{16}$ (excluding South Korea), 6 from Cuba, ${ }^{17} 63$ from Poland, ${ }^{18}$ 8 from Hungary, ${ }^{19} 17$ from Vietnam, ${ }^{20}$ and 1 from Ukraine. ${ }^{21}$

\section{CHURCH-STATE RELATIONS ADDRESSED BY VATICAN II}

As early as during the Council, i.e. on April 11, 1963, the Pope promulgated the encyclical Pacem in terris on the peace among all nations, based on truth,

Thomas, Tissot Faustino, Tou Pao-Zin Petrus, Turner Kenneth Roderick, Van Melckebeke Charles Joseph, Velasco Díaz Juan Bautista, Vérineux André-Jean, Weber Charles, Yüen K'ai-chih Joseph Marie, Yü-Pin Paul.

${ }^{11}$ Beran Josef, Lazik Ambrož, Nécsey Eduard, Pobožný Robert, Tomášek František.

${ }^{12}$ Alaupovič Marko, Arnerić Josip, Bäuerlein Stjepan, Bezmalinović Celestin, Čekada Smiljan, Čule Petar, Držečnik Maksimiljan, Franić Franjo, Gargović Mate, Gugić Giovanni, Jenko Janez, Kuharić Franjo, Lach Josip, Nežić Dragutin, Oblak Marijan, Pavlišić Josip, Pichler Alfred, Pogacnik Jože, Segedi Joakim, Šeper Franjo, Tokić Aleksandar, Ujčić Josip Antun, Vovk Anton, Zazinović Karmelo, Zvekanović Matija.

${ }^{13}$ Arnaud Jean, Berti Leonello, Loosdregt Etienne.

${ }^{14}$ Brizgys Vincentas.

${ }^{15}$ Rancans Jazeps, Urbss Antonijis, Vaivods Julijans.

${ }^{16}$ Bong-kil Sye John, Del Giudice Antonio, Youn Kong-hi Victorinus.

${ }^{17}$ Azcàrate de Andrade Ferdinando, Boza Masvidal Eduardo, Domínguez y Rodríguez José, Riu Anglés Carlos, Rodríguez Herrera Adolfo, Rodríguez Rozas Manuel Pedro.

${ }^{18}$ Ablewicz Jerzy Karol, Baraniak Antoni, Barda Franciszek, Bareła Stefan, Bednorz Herbert, Bejze Bohdan, Bernacki Lucjan, Bieniek Juliusz, Choromański Zygmunt, Czapliński Bernard, Czerniak Jan, Dąbrowski Bronisław, Drzazga Józef, Dudziec Piotr, Etter Tadeusz, Falkowski Czesław, Fondaliński Jan, Gawlina Józef, Goliński Zdzisław, Jaroszewicz Jan, Groblicki Julian, Grzondziel Henryk, Jakiel Stanisław, Jedwabski Franciszek, Jeż Ignacy, Jop Franciszek, Kaczmarek Lech, Kałwa Piotr, Klepacz Michał, Kominek Bolesław, Kowalski Kazimierz, Kowalski Zygfryd, Kulik Jan Wawrzyniec, Kurpas Józef, Latusek Paweł, Majdański Kazimierz, Majewski Wacław, Mazur Jan, Modzelewski Jerzy, Mościcki Aleksander, Muszyński Edward, Nowicki Edmund, Obłąk Jan, Pawłowski Antoni, Pękala Karol, Pietraszko Jan, Pluta Wilhelm, Rubin Władysław, Sikora Bogdan, Skomorucha Wacław, Strąkowski Henryk, Stroba Jerzy, Szwagrzyk Tadeusz, Taborski Bolesław Łukasz, Urban Wincenty, Wilczyński Tomasz, Wójcik Walenty, Wojtyła Karol, Wosiński Jan, Wronka Andrzej, Wycisk Wacław, Wyszyński Stefan, Zaręba Jan.

${ }^{19}$ Bánk Jozsef, Brezanoczy Pal, Cserháti József, Dudás Miklós, Hamvas Endre, Ijjas József, Kovács Sándor, Kovács Vince.

${ }^{20}$ Hoang-van-Doan Dominique, Hoa Nguyen-van-Hien Simon, Jacq André, Le Huu Tu Thaddeus, Ngô-dinh-Thûc Pierre, Nguyên-Khác-Ngu Michel, Nguyên-kim-Diên Philippe, Nguyên-Ngoc-Quang Jacobus, Nguyên-van-Binh Paul, Nguyên-van-Thien Antoine, Palmas Angelo, Pham-ngoc-Chi Pierre, Piquet Marcel, Seitz Paul, Trán-Ván-Thiên Joseph, Truongcao-Dai Joseph, Urrutia Jean-Baptiste.

${ }^{21}$ Slipyj Josyf. 
justice, love and freedom. ${ }^{22}$ The encyclical had a great deal of significance for the conciliar efforts because in it the Pope laid down some guidelines for the determination of mutual relations between the ecclesiastical and the political community. He indicated dialogue as a method of building these relations. Thanks to that it became possible to distinguish between those flawed assumptions of doctrine which should be rejected and people who are to be respected and engaged in dialogue with despite their profession of mistaken ideologies. John XXIII urged Catholics to cooperate also with people with different views.

\subsection{CHURCH-STATE RELATIONS IN THE SCHEMATA OF A DOGMATIC CONSTITUTION ON THE CHURCH}

The work on the relations between the Church and State were assigned to the Theological Commission. In 1962, the Commission drafted a schema of a dogmatic constitution on the Church. It comprised eleven chapters, the ninth entitled De relationibus inter Ecclesiam et Statum necnon de tolerantia religiosa [CAPRILE 1968b, 670] and concerning Church-State relations. Chapter 9 contained the teaching of the Church in respect of mutual relations between the local and the State community, which in the large measure had been established by Pope Leo XIII [SOвCZYK 2005, 36]. In the schema, mutual relations between ecclesiastical and state authority were indicated, and then the duties of secular authority towards religion were demonstrated. The difference between both kinds of authority was highlighted. Each of them should pursue different objectives. With them in mind, the activity of state authority should be subordinate to the realisation of the spiritual goal by the Church, which is greater than that of the State. By its very nature, Church authority is concerned with religious matters, and worldly affairs are dealt with only inasmuch as they serve the supernatural goal. The Church acknowledges different forms of exercising power by the State and accepts the legitimate freedom of State authority. It is interested, however, in matters which pertain to the human person out of concern for the state authorities making such law which does not infringe values of a higher nature. State authority should recognise and appreciate values which society benefits from thanks to the Church [BIALCZYK 1978, 231]. With regard to the duties of secular authority towards religion, the Schema implies that the State cannot assume an indifferent attitude, while the governing entities are expected to assist the subjects so that the latter can live in accordance with the precepts of their faith. Those in authority are also obliged to worship God. The

22 IoANNES PP. XXIII, Litterae encyclicae de pace omnium gentium in veritate, iustitia, caritate, libertate constituenda Pacem in terris (11.04.1963), AAS 55 (1963), pp. 257-304. 
duty to worship God in public is to be fulfilled also by the entire society, which exists by the power of its Creator. The manner in which to worship God should be consistent with His will, therefore the worship should be done in the same way as the Catholic Church does it. State authority is also obliged to receive the revealed truths proclaimed by the Church. While exercising its legislative competence, state authority should be guided by the prescripts of both divine and ecclesiastical law [CAPRILE 1968b, 670-71]. These duties are imposed on the State whose citizens are baptised and the majority of them are members of the Catholic Church. In contrast, in state communities where Catholics are in a minority, they should demand full freedom for themselves, and despite various difficulties in this regard, the Church should endeavour to maintain proper relations with the State [Ibidem, 671].

The schema, redacted on July 17, 1962, was submitted for consideration to a special sub-committee, formed within the Theological Committee, with a view to propose amendments if necessary. The ninth chapter of the schema concerning the Church-State relations was substantially modified. Its was renamed as $D e$ relationibus inter Ecclesiam et Statum. The whole chapter was reviewed to be more general, and the sub-committee members removed, among others, those parts which related to the question of worshipping God by the State in compliance with church rules. In this version, the "Schema of a Dogmatic Constitution on the Church" ${ }^{23}$ was submitted for discussion during the first session of the Council. It was examined on 1 to 6 December 1962 in the course of six sessions of the general congregations (nos. 31-36) [BIALCZYK 1978, 234].

The examination of the entire range of problems addressed by the schema brought the Council Fathers to the conclusion that it should be revised. They announced a thorough amendment of Chapter 9. Highlighting the fact that in nearly all religiously diverse states citizens of different religions lived, Walenty Wójcik, the auxiliary bishop of the diocese of Sandomierz (1914-1990), ${ }^{24}$ proposed in his remarks for the schema that the revised document should include a statement that people who live in two communities at the same time, the religious and the secular one, were harmed not only by a lack of unity but also by the rift between

${ }^{23}$ Schema Constitutionis Dogmaticae de Ecclesia, in: “Acta Synodalia Sacrosancti Concilii Oecumenici Vaticani II" [hereafter AS], vol. I, pars IV, Typis Polyglottis Vaticanis 1971, pp. 12-121. Chapter 9 extended over numbers 40 to 44 and it was split into five parts as follows: 40 Principium: Distinctio inter Ecclesiam et Societatem civilem, et subordinatio finis Civitatis fini Ecclesiae; 41. De potestate Ecclesiae eiusque limitibus, et de officiis Ecclesiae erga Potestatem civilem; 42. Officia religiosa Potestatis civilis; 43. Principium generale applicationis; 44. Conclusio, see pp. 65-74.

${ }^{24}$ Animadversiones scripto exhibitae quod Schema De Ecclesia 81, in: AS, vol. I, pars IV, p. 597. 
the supernatural and the ordinary i.e. natural order ${ }^{25} \mathrm{He}$ also expressed his belief that people were expecting the Council to substantiate the following rules: 1) in her relations with the State, the Church would like to retain the norm of canon 1351 of the Code of Canon Law in its entirety ${ }^{26}$ (no one unwilling is to be coerced into embracing the Catholic faith), and also would like other religious communities to enjoy tolerance safeguarded in laws made by political circles; 2) Catholics would be obliged to defend their freedom of conscience and the freedom of their involvement in church action; 3) Catholic state leaders, inasmuch as they represent the citizens who do not recognise the supernatural mission of the Church, should fulfil their religious duties and in their governance of their subjects they should be guided not only by their Christian conscience but also those demands of the teaching of the Church concerning natural law. ${ }^{27}$

Since the Council Fathers rejected Schema 1, on December 6, 1962, the Coordinating Commission was instituted, whose principal task was to redact amendments for the schema of a dogmatic constitution on the Church. The second version of the schema (Textus Prior), prepared by the Commission, was submitted for evaluation at the outset of the second session of the Council [SoBCzyK 2005, 43]. The schema, which was redacted in 1963, entirely disregarded the issue of relations between the Church and the State [CAPRILE 1968b, 672]. The considerations set out in Chapter 9 of the previous schema were removed due to the fact that a new criterion for the drafting of a dogmatic constitution on the Church was adopted. The idea was that the constitution would govern only the internal matters of the Church [SŁOWIKowsKa 2013, 157].

The dismissal of the issues related to both spheres, that is the church and the state communities, does not imply that these issues were not addressed at all. The schema was comprised of four chapters, the third entitled De populo Dei speciatim de laicis. The debate on that lasted from 16 to 25 October, 1963, during eight general congregations (IL-LVI) [PHILIPs 1966, 141-42]. Its §25 was devoted to the apostolic ministry of the Christian lay faithful. It included a warning that the lay faithful should, on the one hand, avoid undue mixing up of the matters of

\footnotetext{
${ }^{25}$ In this way, Bishop Wójcik highlighted the principle of respect for a pluralistic society, which was subsequently endorsed by the Church at the Second Vatican Council, though it was not provided for in the model of Church-State relations. It can be viewed against a broader background of these relations by examining the constitution Gaudium et spes. For more on this see Sitarz 2015, 116-21 and the related publications.

${ }^{26}$ Codex Iuris Canonici Pii X Pontificis Maximi iussu digestus Benedicti Papae XV auctoritate promulgatus (27.05.1917), AAS 9 (1917), pars II, pp. 1-593.

${ }^{27}$ See W. WóJcik, Załącznik nr 3. Uwagi pisemne przedstawione do schematu o Kościele, in: SiTARZ 2016, 51-53.
} 
religion and the Church with those clearly of a temporal nature, but on the other they should dismiss the "unfortunate hiatus" between the Church and the State, as well as a juxtaposition of the state sphere with God and the Church [BIAtCZYK 1978, 238].

In the course of the debate on the schema, the questions concerning the ChurchState relations were addressed mainly those Council Fathers in whose countries a distinction between the two domains existed. D. Hurley (1915-2004), the archbishop of Durban (South Africa), ${ }^{28}$ and J. Shenan (1898-1984), the archbishop of Baltimore (USA) ${ }^{29}$ made considerable contributions in that respect but the presented study will not address them.

The bishop of the diocese of Łódź, Bishop Michał Klepacz (1893-1967), ${ }^{30}$ took the floor speaking on behalf of the Polish bishops. He suggested that a special section be introduced to address this subject and entitled "Relations of the People of God with the worldly State", the latter conceived as an institution in which the Christian faithful function and constitute it in some measure. The bishop also raised the issue of the coexistence within the same territory, similar political, economic and sociocultural circumstances of the Church and the State. In his view, the policy of the State passes over, omits and disregards Christian ethics and morality. The Church, being its guardian and promoter, should unequivocally define and uncompromisingly pursue her official and pastoral obligation of proclamation of truth, liberty and charity in social and international relations. Speaking of history, he pointed out that the supremacy of the State over the Church is detrimental to humanism and humanity. Bishop Klepacz postulated two ways of building mutual relations between the two: either a concordat or a separation. He observed that beside positive aspects of both alternatives they are not free from negative connotations. If the concordat strategy was adopted, both the State and the Church would gain benefits, as illustrated by, for example, contraction of marriage or education of the young generation. On the other hand, the use of a concordat from the economical point of view lessens the Christians' sense of responsibility which they should manifest towards the Church. ${ }^{31}$ The bishop also warned against the tendency of the secular community to meddle with the internal matters of the Church. He addressed the fact that the State had ignored the arrangements of the international agreement or broke them off in a unilateral manner. Therefore, he was convinced, it would be worthwhile to consider a system of separation between

\footnotetext{
${ }^{28}$ Congregatio generalis LII, 21 octobris 1963, in: AS, vol. II, pars III, p. 158.

${ }^{29}$ Congregatio generalis LIV, 23 octobris 1963, in: AS, vol. II, pars III, p. 242.

${ }^{30}$ Congregatio generalis LI, 18 octobris 1963, in: AS, vol. II, pars III, pp. 99-101.

${ }^{31}$ For more on this obligation see SŁOWIKOWsKa 2017, 123-41.
} 
the two communities. Based on that, the Church may be impartial in judging the actions of particular State governments, and it may be perceived as relentless towards those who violate natural law, while the clergy, who is in no way dependent on secular authority, becomes closer to the People of God [RUTKOwSKI 2014, 138-40]. Concluding his address, Bishop Klepacz requested that the phrase infausta separatio ("unfortunate separation") be expunged from the schema since it implied discontent of the Church with the presence of Church-State separation was present in some states and a longing for unity between these two distinct communities [KRUKOWSKI 1980, 48]. Another postulate was made with respect to the necessity of making the faithful aware of their right - and a duty - to use the mass media and modern technology to foster the faith and to defend good morals, the use of which the was quite often denied to the Church by secular authorities [RUTKOWski 2014, 141].

While discussing Chapter 3 of this schema in the course of the 56th general congregation, Bishop Dragutin Nežić (1908-1995) of the diocese of Poreč-Pula in Yugoslavia (now Croatia) submitted his animadversiones. ${ }^{32}$ In his note he wrote that the intent of the schema drafters was to introduce a distinction between direct and direct ecclesiastical authority, and the thinking that this should suffice was wrong. An inappropriate mixing-up of purely religious matters with purely secular matters gives rise to an impression that human activity can remain outside the authority of God. The draft constitution should capture that idea more transparently. In contrast, with regard to the obedience of man towards secular and civil authority, the bishop observed that the obligation to observe secular law rests not only on secular people but also the clergy because the latter also are citizens of a particular state. Consequently, if the schema was to address the issues related to observance of law on the part of secular society, a separation between the Church and the State is to be implemented. What is more, obedience of both the ecclesiastical and the secular community should be presented as a duty of the faithful fulfilled in a similar, not competitive manner.

Summing up the work on the schemata of a dogmatic constitution on the Church which were prepared first by the Theological Commission in 1962 and then by the Coordinating Commission, we need to bear in mind that there were two standpoints adopted concerning mutual Church-State relations. The first position opposed the idea of total unity between the two communities, while the other concerned a negative appraisal of the separation. These views should be seen in light of the rich experience which the Church had in those countries where such separation

32 Animadversiones scripto exhibitae quod cap. III schematis De Ecclesia 61, in: AS, vol. II, pars III, pp. 511-513. 
had already been implemented. The separation was effectively realised by the State struggling with the Church or these two distinct communities cooperating for the good of the whole society [KRUKOWSKI 1980, 50]. Therefore, the split between the two spheres of activity must not involve a complete lack of mutual relations or even hostility. This separation should arise from sincere cooperation of the two domains and their authorities, since the same people live in both the Church and the State but only their affiliation is different. Due to the fact that the question of Church-State relations constituted a practical problem rather than an issue of doctrine, the Coordinating Commission ultimately removed that from the "Schema on a dogmatic constitution on the Church."

\subsection{CHURCH-STATE RELATIONS IN THE SCHEMATA OF A DECLARATION ON RELIGIOUS FREEDOM}

The range of issues concerning relations between the Church and the State was addressed yet again in another schema drafted for the consideration of the Council. On 19 November 1963, the Council's assembly hall heard the content of the first "Schema of Religious Freedom", which at the time formed Chapter 5 of "The Schema of the Decree on Ecumenism" and was entitled: De libertate religiosa seu de iure personae et communitatum ad libertatem in re religiosa. However, this chapter gradually evolved into a separate document but in the form of an annex to the Decree on Ecumenism. Then it was made entirely separate and became a distinct declaration, which defined the attitude of the Church to the contemporary world [JAWORSKI 2002, 405; WOJTYŁA 2002, 17]. Although the "Schema on Religious Freedom" was made available to the Council Fathers as early as during the second session in 1963, its discussion was postponed until the third session in 1964 for lack of time [SŁOWIKOWSKa 2013, 161].

The schema was divided into four parts, the third one dealing with the question of the freedom of religious communities in public life. During the 85th General Congregation, on 22 September 1964, the apostolic administrator in Gorzów Wielkopolski Bishop Wilhelm Pluta (1910-1986) ${ }^{33}$ regretted that the schema on the pastoral activity of the Church had been removed. He stressed that the subject could not be dispensed with and urged the Council Fathers to issue a pastoral declaration.

In the course of the debate on the schema on religious freedom, during the 87th general congregation convened on 24 September 1964, the floor was taken by Bishop Klepacz, ${ }^{34}$ who argued that every person had the right to profess any

33 Congregatio generalis $L X X X V$, 22 septembris 1964, in: AS, vol. III, pars II, p. 261.

${ }^{34}$ Congregatio generalis LXXXVII, 24 septembris 1964, in: AS, vol. III, pars II, p. 505. 
religion of their choice. Every person had the right to live by the precepts of their faith, while any restriction of their freedom in this regard constituted a breach of their rights. The Council Father came in favour of tolerance of different beliefs. He alluded to the origins or foundations of freedom, especially religious freedom. $\mathrm{He}$ made references to John XXIII's encyclical Pacem in terris, indicating that freedom is founded upon truth, justice, solidarity and charity. Justice, in equal measure, is binding for all individuals, societies and states, and freedom safeguards peace and progress. We need to be vigilant so that freedom is not abused. However, abuses do occur when not so much religion but its followers use dishonourable means. Additionally, a mistaken understanding of freedom adds to indifference. In conrast, a proper conception of religious freedom fosters suitable relationships among people, between an individual and the community, and between the State and its citizens [RUTKOWSKI 2014, 205-206].

Also, during the 88th general congregation, convened on 25 September 1964, Archbishop Karol Wojtyła, the metropolitan of Kraków (1920-2005), took the opportunity to raise the subject of religious freedom. ${ }^{35} \mathrm{He}$ made reference to the recipients of the schema at hand. On the one hand, the schema of the declaration on religious freedom was addressed to the separated brethren and concerned the internal affairs of the Church (ad intra), while on the other hand it dealt with the governing bodies of societies, thus determining the attitude of the Church towards the world (ad extra). According to the hierarch, the proposed arrangement of these extremely important questions addressing two very different recipients was not a good idea. For that reason, he proposed that those matters be moved to the 13th schema. What is more, Archbishop Wojtyła addressed the relationship between freedom and truth, which he believed were not possible to be subsumed under one notion, i.e. tolerance. Tolerance should reflect the State's attitude towards its citizens who have the fundamental right to have their religious freedom respected. The right to religious freedom coexists with, among others, the right to know and convey the truth, and with the right to personal and private life as well as social and public life, all in the light of the truth about man. Hence the appeal, articulated by the archbishop of Kraków, for this truth to be forcefully and effectively put on view in dialogue with the world [RUTKOwSKI 2014, 206-207].

During the 4th session of the Council, the Fathers continued to deliberate the declaration on religious freedom. It was debated from the 15 th to the 22 nd of September 1965 (general congregations nos. 128-133) and on 25 October 1965 (the 164th general congregation) to put it to a vote on the 27th and 29th of October

${ }^{35}$ Congregatio generalis LXXXVIII, 25 septembris 1964, in: AS, vol. III, pars II, p. 532. For details on the participation of K. Wojtyła in Vaticanum II, see SKRZYPCZAK 2011. 
1965 (general congregations no. 154 and 155) and on the 19 of November 1965 (the 164th general congregation). The final voting of the declaration took place on 7 December 1965 during the ninth public session. On that day the document was promulgated.

Major Archbishop of Lviv, Cardinal Josyf Slipyj, spoke on behalf of some of the patriarchs and Eastern bishops and the Episcopal Conference of Ukraine during the 129th general congregation on 16 September $1965 .{ }^{36}$ He proposed that the schema of the declaration on religious freedom commence with the affirmation of human dignity as that was the origin of all freedom. He also emphasised that in the recent decades the sociological limits of human rights and the rights of the State had been drawn in order to ensure that citizens live a life of peace and order, but those limits are still being considered in relation to religion. For that reason, the Council's task was to draw those limits for the religious life of the faithful. By making reference to the words of the schema saying "In the Catholic tradition, religious freedom is the foundation of human existence in relations between the Church and the secular order," he proposed that that thought be developed and the schema supplemented so that it would say that the Church believed in religious freedom in the future and never denied it, defending the inalienable rights vigorously and enjoying the authority of an ideal community.

During the same congregation the floor was taken by Bishop Stanislaus Lokuang (1911-2004) [also known as Lo Kuang], the bishop of the diocese of Tainan in China ${ }^{37}$ He pointed out the ambiguity in the presentation of the very sense of the notion of religious freedom. Freedom, also religious, should be conceived as freedom to choose one's conscience regardless whether this choice was between the freedom of faith or the freedom to practice it in social order.

During the 130 general congregation, on 17 September 1995, Franjo Šeper (1905-1981), the metropolitan of Zagreb (Yugoslavia), ${ }^{38} 17$ September 1965 spoke about the essence of religious freedom as the basis of the flowering of people's religious life. He indicated that oppression and abuses in this respect are possible therefore it is necessary to make the general public who reject religious freedom realise that it is must not be infringed or destroyed. He appealed to the Council Fathers to pay special attention to this issue because it belongs to the Church to provide a precise formulation of the teaching on religious freedom so that it will become currently relevant and comprehensible for the modern world. What is the most important, in his opinion, is not the verbalisation of the very religious

\footnotetext{
${ }^{36}$ Congregatio generalis $C X X X, 16$ septembris 1965, in: AS, vol. IV, pars I, pp. 236-239.

${ }^{37}$ Ibidem, 250-251.

${ }^{38}$ Congregatio generalis CXXX, 17 septembris 1965, in: AS, vol. IV, pars I, pp. 292-294.
} 
freedom, but what poses a serious problem is a disturbed balance between various religious communities living in secular societies of that day (states). Obviously, it can be supposed that these communities ensure the fulfilment of civic rights such as provision of specific kinds of religious or spiritual assistance, that is exactly what religious freedom is about. However, it must be emphasised that the scope of activity which religious freedom involves was not bestowed upon people under secular law but it is an innate and inalienable human right.

On that same day, Archbishop Antoni Baraniak (1904-1977), the metropolitan of Poznań, spoke. ${ }^{39}$ In his analysis of the schema he pinpointed its weaknesses. In this regard he mentioned, for example, some statements which could give rise to false interpretations, being detrimental to both the Church and religious freedom. Similarly to Šeper, among the potential threats to religious freedom he saw religious communities themselves. He postulated that it should be confessed that in the course of the Church's history there may have existed institutions that breached religious freedom. This would ensure due satisfaction to those who had endured any suffering on that account, as well as constitute a proof that the Church craves for constructive dialogue with people who have different religious convictions. The archbishop also proposed that the word "coercion" (coactio) used by the schema in its definition of religious freedom should be explained, and that it should be clearly emphasised that a legal norm should be compliant with a moral principle, namely it should be equitable and beneficial. He also asked for development and further elaboration of notions related to the subjective and objective truthfulness of religion. That specification would indicate the internal difference between legal religious freedom, enjoyed by Christians, and legal religious freedom enjoyed by followers of other religions. He also postulated that the declaration should avoid any references which could be suggestive of legal positivism [RUTKOWSKI 2014, 255-56].

Several days later, on 20 September 1965, a speech was delivered by the Primate of Poland Cardinal Stefan Wyszyński (1901-1981). At the 131th general congregation (1901-1981). ${ }^{40}$ He proposed that such notions as "world", "law", "state" and "freedom" should receive a clear definition during the debate, as they were conceived differently in accordance with the teaching of the Church and the rules of dialectic materialism. Wyszyński illustrated the differences in this respect using the example of the encyclical Pacem in terris, which was interpreted in the world as an expression of support for peace but the elements and ways of attaining that peace were interpreted differently. The primate of Poland requested that the text of

\footnotetext{
${ }^{39}$ Ibidem, p. 306.

${ }^{40}$ Congregatio generalis CXXXI, 20 septembris 1965, in: AS, vol. IV, pars I, pp. 387-390.
} 
the declaration be preceded with a suitable introduction expounding the said notions [RUTKOWSKi 2014, 256-258]. In this context, the words of the cardinal should be analysed at a greater depth, hence let us recall expressly: "This all seems to me necessary for understanding and a just assessment of the situation of the Church in the world which is guided by notions derived from the so-called diamat. Alas! There are so many authors... who take up this issue without a proper understanding of it. This is because what they have in mind is the laws and principles applied in the West. This is also the reason why our bishops are charged with conservatism as though they wished to retain the rules of obsolete feudalism. What we are speaking of is not feudalism or privileges but the right to life and doubtlessly the apostolic life of the Church. [...] They will of course say: we do recognise «the right to truth» but within the limits defined by the so-called diamat. The right to freedom - they continued - lies within the limits of law made by the postulates of the State, i.e. the state community. The right to freedom entails the freedom of action under leadership or under duress but always in accordance with the precepts and assumptions of the «diamat» and for the benefit of governments devoted to collectivism. The notion of «freedom» must not be derived from the nature of the human person and using the principles of a well-formed conscience but from the premises which contribute to social transformation conducted in the spirit of the so-called diamat. [...] We should always keep in mind [the fact] that a large part of our world is subject to rules grounded in regime which believes in rights, states and liberties that are different to our tradition. These notions are imposed on people who are subjects of or, more appropriately, faithful of the Church [...]." ${ }^{\prime 41}$ In the closing fragment of his speech, the primate of Poland noted that he would very much appreciate it if the Council would promulgate the declaration on religious freedom but he would very much like it to be understood and implemented in the same way everywhere.

The primate of Poland was followed by Josef Beran (1888-1969), the metropolitan of Prague (Czechoslovakia), ${ }^{42}$ who shared his experiences from his country, where the freedom of conscience had been radically restricted. Both the lay faithful and the clergy were equally affected. In his dramatic address, the cardinal said that the Catholic Church in his country lived as if under occupation, in hiding. For that reason he urged the participants of the Council to add a text to the final part of the declaration which would declare the Church's prayer to God Who would

${ }^{41}$ Quoted after: Wypowiedź kard. Stefana Wyszyńskiego podczas dyskusji nad schematem deklaracji De libertate religiosa, Rzym, 20 września 1965 [CXXXI kongregacja generalna], translated into Polish by Z. Perz, in: WiLK and WóJcik 2013, 268-69.

42 Congregatio generalis CXXXI, 20 septembris 1965, in: AS, vol. IV, pars I, pp. 393-394. 
deliver the oppressed and incarcerated on account of their faith and enable people exercising their religious freedom to freely choose their way of life, be it priesthood or religious orders, and to be able to raise their children in the Christian faith.

In a written note concerning the text of the declaration and submitted during the 132nd congregation, Archbishop Jože Pogačnik (1902-1980), the metropolitan of Ljubljana (Yugoslavia), ${ }^{43}$ voiced his concern about the proposed teaching. Although he was in favour with it in its entirety, he observed that a declaration made in such a form would cause serious difficulties for the Church in some countries.

On 22 September 1965, during the 133rd general congregation, Archbishop Wojtyła addressed ${ }^{44}$ the participants to say that he thought it was important that the declaration demonstrate the close relationship between freedom and responsibility. Although the text of the declaration pertained to secular authority, it applied primarily and directly to the human person. While acknowledging the right of the human person to freedom in religious matters, the Council should simultaneously emphasise responsibility in this respect and with regard to the application of this right. With the help of the Council's declaration, each human person should be able to affirm not only his freedom but also personal responsibility for religious matters. The introduction of appropriate amendments emphasising responsibility - in the metropolitan's view - caused that the declaration would be far from promoting liberalism or indifference, being now profoundly personalistic in the Christian sense. Archbishop Wojtyła also made it clear that any restriction of people's religious freedom can be accounted for only when the application of this freedom infringes moral rights [RUTKOwsKi 2014, 258-60].

\subsection{CHURCH-STATE RELATIONS IN THE SCHEMATA OF A PASTORAL CONSTITUTION ON THE CHURCH IN THE MODERN WORLD}

The history of the pastoral constitution on the Church in the modern world, which was entitled "Schema XIII" (initially XVII) while it was being redacted and debated, is shorter than the origins of the documents referred to above. During the preparatory phase of the Second Vatican Council no such document was envisaged. However, after the decision was taken to define the Church's position regarding secular community, as many as 17 schemata of the number 76 of the constitution Gaudium et spes were drafted, in which this position was explained [SitARZ 2013, 56].

${ }^{43}$ Animadversiones scripto exhibitae quod schema decreti de liberate religiosa inter periodum III et $I V, 103$, in: AS, vol. IV, pars I, p. 828.

${ }^{44}$ Congregatio generalis CXXXIII, 22 septembris 1965, in: AS, vol. IV, pars II, p. 11. 
The preparation of a separate schema was commenced in the January of 1963, when the Coordinating Commission ordered a mixed commission, comprised of the members of the Theological Commission and the Commission for the Apostolate of the Laity, to prepare a draft of the document De praesentia Ecclesiae in mundo hodierno. The work began in February and on 25 March 1963 the mixed commission submitted the schema to the Coordinating Commission [CAPRILE 1968a, 634-35]. ${ }^{45}$ During the examination of the document some gaps were revealed so the reworking thereof was ordered. To that end, a group of experts of the Leuven Catholic University was appointed who prepared a document entitled "Draft Schema XVII on the active presence of the Church in the building of the world" (Adumbratio schematis XVII de activa praesentia Ecclesiae in mundo aedificando) ${ }^{46}$ After the outcomes of these efforts had been analysed, it was proposed that a central sub-commission be appointed whose task would be to completely rework the project since the schema produced by the Leuven group was criticised for marginalising the most crucial problems of humanity and for failing to meet the expectations of contemporary people [WeNGER 1963, 386]. The sub-commission started off by directing a request to the bishops and other clerics and lay people of other countries to express their opinion on the outline of the schema. Thus redacted, the draft was translated from French into Latin and in March 1964 it was conveyed by the central sub-commission to the mixed commission. ${ }^{47}$ The text, however, went back to the central sub-commission. Having reviewed the draft, the mixed commission approved it and had it handed over to the Coordinating Commission. When the latter approved the text, Pope Paul VI ordered the text to be distributed among the Council Fathers. ${ }^{48}$ Ultimately, the text which now was entitled "Schema 13" consisted of an introduction, four chapters ${ }^{49}$ and a conclusion. Five annexes were appended to it. ${ }^{50}$ It should be observed that this schema missed a direct reference

${ }^{45}$ It should be noted that C. Moeller enumerates six drafts of the "Schema of the Pastoral Constitution on the Church in the Modern World" [Moeller 1968, 242-78].

${ }^{46}$ A. Guano, Relatio. I. Historia Schematis, in: AS, vol. III, pars V, p. 142.

${ }^{47}$ Ibidem, pp. 143-144.

${ }^{48}$ Schema de Ecclesia in mundo huius temporis, in: AS, vol. III, pars V, p. 116-142.

${ }^{49}$ The chapters dealt with such issues as the following: 1) integral conception of the vocation of the human being (de integra hominis vocatione); 2) the ancillary role of the Church towards people (Ecclesia Dei hominique servitio dedita); 3) the Christian attitude towards the world (de ratione christianorum se gerendi in mundo in quo vivunt); and 4) special tasks of the Christians in the world of today (de praecipuis muneribus a christianis nostrae aetatis implendis).

${ }^{50}$ The annexes addressed the following questions: 1) the human person in society (de persona humana in societate); 2) matrimony and family (de matrimonio et familia);3) the proper development of culture (de culturae progressu rite promovendo); 4) economic and social life (de vita oeconomica et sociali); and 5) the community of nations and peace (de communitate gentium et pace). 
to the Church-State relation. Only Annex 1 in Part C (De relatione inter hominem et societatem atque potestate politicam) and Annex 3 in Part D (De Ecclesia in societate hominum) mentioned the necessity of there being a political community and a supreme authority. Such authority is necessary for the building of common good, and its goal is to attain freedom and improvement of human life. The Church differs from the secular community and pursues different goals. For both, however, there is a need for peaceful cooperation [Nowacki 1982, 56-57; SŁOWIKowsKa 2013, 163-64].

Thus prepared, the schema was submitted for discussion on 17 September 1964. The debate commenced at the 105 general congregation on 20 October 1964.

The speech made by Archbishop Maxym Hermaniuk (1911-1996) ${ }^{51}$ was significant in the light of Church-State relations. Although he did not represent any state from the Communist Bloc among the Council Fathers because at the time he held the office of archbishop of Winnipeg in Canada for the faithful of the Ukrainian Catholic Church, he knew the reality of communism and its attitude towards religion, being a Ukrainian himself. For these reasons we should adduce his position on the draft pastoral constitution on the Church in the modern world. He proposed that Schema 13 should start by defining the notions "world" and "Church" in the theological sense as they had to be mutually defining in that document. Without a precise determination of these the draft could lend itself to ambiguity. He proposed the following definition of the world: "The entire human community on Earth, called at the same time by God as one, pertaining to practical aspects of human life in religious, scientific, cultural, social, economic and political matters." In Hermaniuk's view, the vital mission of the Church in the world consists in helping people to experience these aspects and consolidation of the faithful in their integral vocation. Then he postulated that the schema contain a description of everyday life experience of the faithful who live, as it were, in two distinct systems: the Christian world and Marxist materialism, which suppresses any movements that are more or less religious or philosophical. His argumentation was that it was for those reasons that the presence of the Church in the contemporary world was so vital. The defective nature of Marxism and Communism consisted in the fact that the atheists supporting that ideology would claim that Christianity hindered progress in the building of the world's community by employing visions of the supernatural world.

${ }^{51}$ Congregatio generalis CVI, 21 septembris 1964, in: AS, vol. III, pars V, pp. 296-298. See also: The Second Vatican Council Diaries of Met. Maxim Hermaniuk, C.Ss.R. (1960-1965), trans. J.Z. Skira, Peeters Publishers, Pap/Cdr edition, Leuven-Paris-Walpole 2012. 
Archbishop Wojtyła, one the Polish Council Fathers, took the floor on 21 October 1964 during the 106th general congregation. ${ }^{52}$ He began by making reference to his criticism of the idea to combine recipients and the contents of the schema. He also pointed out that in the diverse world we live in, depending on the circumstances, one time the Church is needed and another time it is done away with. According to the hierarch, the purpose of the schema was to justify and normalise the ancillary interpenetration of In his view, the draft had to be revised so that the Church would be presented to the world, its foundations revealed, and its objectives and means defined. The document should reach the people living in the contemporary world, addressing their problems and defending their rights [RUTKOwSKI 2014, 217-19].

During the 109th general congregation, on 26 October 1964, Bishop Jan Pietraszko, the auxiliary bishop of the diocese of Kraków, took the floor. ${ }^{53} \mathrm{He}$ drew the Fathers' attention to the introduction to Chapter 1. For Pietraszko, it was of key importance to explain the notion of "world", that the way the Church understood it. He argued that a new generation of people was growing who virtually had no theological vision of the Church. They regarded the world as entirely their own domain and as a result they either used or abused that world. God, in contrast, was regarded as an alien being, and as an aggressor with respect to His commandments. It is to those people that the vision of the world had to be shown anew [Rutkowski 2014, 219-20].

Cardinal Wyszyński spoke during the 114th general congregation on 4 November $1964 .{ }^{54}$ Firstly, he expressed his critical view of the schema, claiming that many of its issues were treated in an academic manner, yet they have practical implications in people's everyday life. He focused chiefly on economic issues, and suggested that the schema should be reviewed so that it would demonstrate the perilous effects of an economy called an "economic system", devoid of any moral grounding, which is detrimental not only to individuals but also to the very production of goods. Wyszyński underscored the fact that these phenomena take place both under economic liberalism and in the system of universal enslavement, namely collectivism. It must be demanded that economic systems utilise philosophical and ethical principles. Moreover, the attitude of an economic political system to religion should receive attention in its own right since not in every economic system the Church is enabled to operate freely. Cardinal Wyszyński also took sides with workers and their rights, especially those of working immigrants, who

\footnotetext{
${ }^{52}$ Congregatio generalis CVI, 21 septembris 1964, in: AS, vol. III, pars V, p. 298.

${ }^{53}$ Congregatio generalis CVI, 21 septembris 1964, in: AS, vol. III, pars V, p. 518.

${ }^{54}$ Congregatio generalis CXIV, 4 novembris 1964, in: AS, vol. III, pars VI, pp. 272-275.
} 
strove to increase the economic well-being of the State but were denied civil and social rights. ${ }^{55}$

During the last conciliar session, i.e. from the 21 September to the 8th October 1965, the text of the pastoral constitution on the Church in the modern world was debated. In November, 163 notes on the schema were analysed, and a new revision was drafted. On 17-19 November 1965 various votes on the particular items were taken, but more amendments were considered to further modify the schema. During the 168th general (final) session, the entirety of the drafted document was put to a vote. It was approved during the ninth public session of Vatican II, on 7 December 1965 [Rutkowski 2014, 261].

During the 134th general congregation, convened on 23 September 1965, the floor was taken by Archbishop Bolesław Kominek (1903-1974), the metropolitan of the Wrocław diocese. ${ }^{56} \mathrm{He}$ expressed his dissatisfaction with the rather vague treatment of the issues related to the political community. He emphasised that it was unacceptable to resolve border conflicts in the course of war and recommended the solutions provided by John XXIII in his encyclical Pacem in terris [RUTKOwSKI 2014, 262; Mutor 2013, 83-99].

In the 136th general congregation, on 27 September 1965, Bishop Klepacz ${ }^{57}$ asked the Council Fathers to include in the constitution an appeal to all authorities, states and nations not to break the fifth commandment (ne quintum Decalogi praeceptum violent). In his opinion, any pro-life organisations which are based on codified law must remember that it belongs to every kind of authority to take care of individuals and consequently societies and mankind. Man is both the point of departure and the goal for all agreements, laws and constitutions. This obligation originates in the Gospel [RUTKOWsKi 2014, 264-65]. ${ }^{58}$

A day later, on 28 September 1965, during the 137th general congregation, Archbishop Wojtyła spoke. ${ }^{59}$ He pointed out the flaws of the schema visible in

${ }^{55}$ See Wypowiedź kard. Stefana Wyszyńskiego na temat rozdziału IV schematu De Ecclesia in mundo huius temporis, Rzym, 4 listopada 1964 [CXIV kongregacja generalna], trans. Z. Perz, in: WILK and WóJCIK 2013, 240-42.

${ }^{56}$ Congregatio generalis CXXXIV, 23 septembris 1965, in: AS, vol. IV, pars II, pp. 387-389.

${ }^{57}$ Congregatio generalis $C X X X V L, 27$ septembris 1965, in: AS, vol. IV, pars II, p. 467.

${ }^{58}$ It should be noted that Bishop Klepacz referred to Schema 13 also during the 144th general congregation convened on 7 October 1965, addressing the issue of world peace. He proposed that the schema be revised in observance of the indications issued by Popes John XXIII and Paul VI concerning the measures which promote peace, abolition of colonialism, protection of the rights of poor and weak nations. The amendments of this part of the schema should be consider that fact that peace is the fruit of justice and morality. See Congregatio generalis CXLII, 7 octobris 1965, in: AS, vol. IV, pars III, pp. 647-649 [RUTKоwsKi 2014, 273-74].

${ }^{59}$ Congregatio generalis CXXXVII, 28 septembris 1965, in: AS, vol. IV, pars II, p. 661. 
its fragment devoted to dialogue between the Church and the world since - in his opinion - it was overwhelmed by a vision of the world as it should be rather than what it was, while the presence of the Church in it was not sufficiently real. Moreover, atheism pervading the world should be viewed as the internal state of the person, the problem of the mind, will and heart, and as the problem of being separated from God, a state with denies immortality but is immortalised in the collective. He insisted that it should be remembered that the atheist world sees religion as a path to idealistic alienation and it imposes on the faithful the visible and tangible reality [RUTKOWSKI 2014, 265-66]. According to the commentators reviewing that fragment of Wojtyła's speech, "the consideration of this phenomenon by the Polish speaker [...] from the perspective of civil tolerance and civil equality before the law was seen by the conciliar Fathers as an evident testimony to the authentic contribution - enriching the contemporary thought of the Church - which could be afforded by the Catholic Church in the socialist countries." 60

Also, on the next day, 29 September 1965, during the 138th general congregation, the floor was taken by Bishop Kazimierz Majdański, the auxiliary bishop of the diocese of Wrocław. ${ }^{61}$ His speech was focused on matters related to pro-life support. He posed a dramatic question to the following issue: "When the world remains silent about this, should the Church not speak out all the more clearly and distinctly on this subject?"62 He appealed to the Council Fathers to prepare a special declaration on the inviolability of each innocent and unborn life, in which the Church should sincerely and unhypocritically come in favour of the commandment "Thou shall not kill!", point out moral mistakes in the area of sexuality, and emphasise the fact that abortion compromises human dignity and the basis of equality of all people. This appeal was preceded by a recollection of the horrifying statistics saying that the annual number of conceived but unborn babies (abortions) disproportionally exceeded the number of deaths resulting from World War II. He emphasised the tragic dimension of that situation, pointing out that this state of affairs was perpetuated by both individuals and whole Christian families. What is more, religious indifference and ethical relativism were effectively breaking the foundations of sexual and marital life, calling maternity and fatherhood into question, overturning the foundations of entire societies, cultures and the human civilisation. Bishop Majdański further underscored the fact these destructive processes received support from state legislation [RUTKOwSKI 2014, 268-69].

${ }^{60}$ Nasz specjalny wystannik Mikołaj Rostworowski telefonuje z Rzymu: Poza Aula $i$ w Auli, "Słowo Powszechne" year 18 (1965), no. 233, p. 2.

${ }^{61}$ Congregatio generalis CXXXVIII, 29 septembris 1965, in: AS, vol. IV, pars III, p. 43.

${ }^{62}$ Ibidem. 
In a similar vein, the auxiliary bishop of Katowice, Herbert Bednorz, spoke at the 139th general congregation on 30 September $1965 .{ }^{63}$ Devoting his address to marital and family life, he pointed out the crisis of human life in the industrialised world, where the permanence of marriage was being continuously challenged. The crisis is felt particularly sharply by women, wives, mothers and children. The circumstance in which the contemporary world exists do not foster family education, the responsibility which is being increasingly delegated to school, Church or social organisations. The speaker underscored the importance of the involvement of parents and elder siblings in the formation of new family members, the faithful of the Church and citizens of the State. On the other hand, however, it would be cruel to speak only of educational burden resting on parents while disregarding the fact that it is the Church and the State - as communities intended to serve man - should help us in that task, creating adequate living conditions so that family could fulfil its tasks properly [RUTKOWSKi 2014, 269-70].

On 5 October 1965, during the 142nd general congregation, the Primate of Poland stood up for the social rights of man. ${ }^{64} \mathrm{He}$ postulated that the proposed pastoral constitution on the Church in the modern world be supplemented with an appropriate historical introduction showing that the conciliar teaching drew on the Church's existing views and experience to date. In this regard, the questions of human work are significant as they need to be solved because no solution has been found in the world of capitalism and communism, systems which proclaim the primacy of matter over man and production over human dignity. For that reason, in Cardinal's opinion, a doctrine which puts man before matter is to be regarded highly. Underscoring the essence of education, the hierarch affirmed workers' rights. He pointed out that individual people are plagued by the insufficiency of material goods despite living in economic systems where industrial production is being stepped up. People are producing more and more, receiving a paltry remuneration for their work. He appealed that a solution be incorporated in Schema 13 which had been postulated by Pope John XXIII [RUTKowsKi 2014, 270-71]. ${ }^{65}$

The address delivered by Archbishop A. Baraniak ${ }^{66}$ on the same day and before the same general congregation was immensely important. He directly addressed Chapter 4 of Schema 13, devoted to relations between the Christians and the political community. The metropolitan of Poznań expressed his conviction that it was

${ }^{63}$ Congregatio generalis $C X X X I X, 30$ septembris 1965, in: AS, vol. IV, pars III, p. 90.

${ }^{64}$ Congregatio generalis CXLII, 5 octobris 1965, in: AS, vol. IV, pars III, pp. 360-363.

${ }^{65}$ See Wypowiedź kard. Stefana Wyszyńskiego podczas dyskusji nad druga częścia schematu De Ecclesia in mundo huius temporis, Rzym, 5 października 1965 [CXLII kongregacja generalna], trans. Z. Perz, in: WiLK and WóJCIK 2013, 274-76.

${ }^{66}$ Congregatio generalis CXLII, 5 octobris 1965, in: AS, vol. IV, pars III, pp. 392-393. 
vital to ensure cooperation between the governing authority and the ecclesiastical community. He indicated the possibility of undertaking cooperation between the Christian faithful and the atheist, totalitarian and religion-hostile government (de cooperatione christifidelium; cooperatio cum regimine atheistico, totalitarno et religio nem debellante). He highlighted the fact that life was extremely tough for the Christians living in totalitarian states because their governments were imposing on their citizens the duty to cooperate in order to build and spread socialism regarded as the ultimate common good. The archbishop argued that Christians should on no account become involved in such cooperation, yet being members of the Church who is alive and developing also in socialist states, we should answer the question "if and on what conditions we can cooperate with governments of that sort in matters which are essentially beneficial but possibly lending themselves to abuse, for example to introduce atheism." Archbishop Baraniak also urged the Council Fathers to deliberate the dilemma arising from the necessity of drawing a line between the ruling powers which share the teaching about sources, purpose and law application with the Church and countries whose rulers are follow atheist theories. In the first case, in Baraniak's view, the Church embodies by the Council Fathers can say that citizens bound by obiedience in their conscience, but in the latter case this difficulty must be resolved by the very Schema and the rules of conduct should be laid down for the faithful. Therefore the speaker expressed his hope that the Schema would undergo a revision so that it would now reflect the issue of cooperation of the Christian faithful with atheist governments, outlining the boundaries which could not be overstepped [RUTKOwSKI 2014, 271-72].

\section{EVALUATION OF THE REAL CONTRIBUTION TO THE TEACHING OF THE COUNCIL}

To recapitulate our considerations of the issue at hand, we need to refer to the real contribution that the Council Fathers from the communist states existing at that time made to the resolutions promulgated by Pope Paul VI, which addressed Church-State relations. In accordance with our research goal, we need to amend the statement by Cardinal Poupard, quoted at the beginning. This viewpoint is hard to subscribe to. This judgemental opinion is not true despite the actual and quite obvious involvement of Archbishop Wojtyła in the work of the Council. The existing model of Church $\square$ State relations, developed by Vatican II at the time, was influenced by many bishops from all over the world. The contribution of the bishops from the Communist Bloc to the teaching of the Council must not be credited to one man only. Our study has demonstrated the involvement of many 
participants originating from behind "the Iron Curtain" and their courage when saying the truth. Moreover, they were not the only ones engaged in the debate on those matters during Vatican II. Some equally significant views were presented by the representatives of other countries, receiving approval of the bishops from the Communist Bloc.

Remarks concerning mutual relations between the two communities of different character, that is the Church and the State, expressed by the Council Fathers from the Communist Bloc in their addresses delivered in the assembly hall or submitted in writing as animadversiones, found their manifestation in both the declaration on religious freedom Dignitatis humanae and in the pastoral constitution on the Church in the modern world Gaudium et spes.

Therefore, the modifications of the declaration on religious freedom were the following:

- the introduction was reworked in line with the suggestions presented by the Primate of Poland to highlight human dignity as the source of religious freedom, indicating the limits of this freedom (Dignitatis humanae 2), the latter requested by Archbishops Slipyj and Baraniak;

- the right to religious freedom proper to every human being was emphasised (Dignitatis humanae 2) as requested by Bishop Klepacz;

- the very notion of religious freedom was specified (Dignitatis humanae 4) in the manner indicated by Bishop Lokuang. It was now clarified that the word "coercion" should be viewed as being integral with the definition of freedom while taking into account its individual aspects. In this context, freedom is taken to be human immunity from compulsion to act against one's conscience (Dignitatis humanae 2), the concern which had been articulated by Bishop Baraniak;

- special attention was given to parental entitlement to educate children in the faith (Dignitatis humanae 5), as urgently advocated by Cardinal Beran, although the declaration ultimately did not include the assurance - requested by Beran - of the Church's prayer for those suffering on account of their faith (cf. Dignitatis humanae 14);

- a close connection between freedom and responsibility (Dignitatis humanae 7) was demonstrated, which was requested by Archbishop Wojtyła.

The pastoral constitution on the Church in the modern world underwent the following amendments:

- a definition of the world was introduced (Gaudium et spes 2), as Archbishops Hermaniuk and Pietraszko had insisted;

- the teaching on atheism and attitude of the Church towards it was elaborated on (Gaudium et spes 19-21), as requested by Archbishop Wojtyła; 
- the subject of political community was expanded and accordingly the whole Chapter 5 was devoted to it, to satisfy the demands of Archbishop Kominek in this respect;

- the pluralism of world views and pluralistic society were given appropriate consideration, which had been mentioned by Bishop Wójcik;

- the mutual independence of the Church and the political community (Gaudium et spes 76) were accounted for, the state which Bishop Klepacz had indicated as a possible relationship between these two communities;

- an indication was included that also Christians had to fulfil their obligations as citizens of the State (Gaudium et spes 75), which had been pointed out by Bishop Nežić;

- the need for cooperation between the Church and the political community was expressed (Gaudium et spes 76), as addressed by Archbishop Baraniak;

- the rights of foreign workers and immigrants were addressed (Gaudium et spes 27), as advocated by Cardinal Wyszyński;

- the need for helping families (Gaudium et spes 52) was underscored, as requested by Bishop Bednorz;

- and finally - though not in the form of a separate declaration - an unequivocal position of the Church regarding the issue of respect for human life and inadmissibility of abortion was expressed (Gaudium et spes 27, 51), which had been called for by Bishops Klepacz and Majdański.

\section{REFERENCES}

1965. "Nasz specjalny wysłannik Mikołaj Rostworowski telefonuje z Rzymu: Poza Aulą i w Auli." Stowo Powszechne 18(233):2.

2012. The Second Vatican Council Diaries of Met. Maxim Hermaniuk, C.Ss.R. (1960-1965), trans. Jaroslav Z. Skira. Leuven-Paris-Walpole: Peeters Publishers, Pap/Cdr edition.

BiAŁCZYK, Andrzej. 1978. Rozdział między Kościołem a państwem w świetle nauki Kościoła katolickiego, a typed document in the KUL archive. Lublin: Katolicki Uniwersytet Lubelski.

CAPRILE, Giovanii. 1968a. "Die Chronik des Konzils und der nachkonziliaren Arbeit vom Oktober 1958 bis Dezember 1967." Lexikon für Theologie und Kirche 3:624-64.

CAPRILE, Giovanii. 1968b. "Entstehungsgeschichte und Inhalt der vorbereiteten Schemata. Die Vorbereitungsorgane des Konzils und ihre Arbeit." Lexikon für Theologie und Kirche 3:665-726.

Churchill, Winston. 1974. "Sinews of Peace." In James R. Rhodes, Winston S. Churchill: His Complete Speeches 1897-1963. Vol. VII: 1943-1949, 7285-293. New York: Chelsea House Publishers, R.R. Bowker.

GoeBBels, Joseph. 2000. "Das Jahr 2000.” In https://archive.org/stream/GoebbelsSpeechesArticlesComplete/GoebbelsSpeechesArticlesFromCalvin.edu.Complete_djvu.txt. [the English translation accessed March 13, 2018]. 
JAWORSKI, Marian. 2002. “Wprowadzenie do Deklaracji o Wolności Religijnej.” In SoBóR WaTYKAŃSKi II. Konstytucje, dekrety, deklaracje. Polish text, new translation, 405-409. Poznań: Pallottinum. KRUKowsKi, Józef. 1980. "Stanowisko Soboru Watykańskiego II wobec rozdziału Kościoła od państwa." Roczniki Teologiczno-Kanoniczne 27(5):45-63.

Krukowski, Józef. 2000. Kościót i państwo. Podstawy relacji prawnych, 2nd ed. Lublin: Redakcja Wydawnictw KUL.

Melloni, Alberto (edited by). 2015. Atlas historyczny Soboru Watykańskiego II, trans. Paweł Borkowski. Warszawa: Instytut Wydawniczy PAX.

MiszTaL, Henryk. 2003. “Okres 1945-1989.” In Prawo wyznaniowe, edited by Henryk Misztal, and Piotr Stanisz, 2nd ed., 128-72. Lublin: Wydawnictwo Diecezjalne Sandomierz.

Moeller, Charles. 1968. "Die Geschichte der Pastoralkonstitution." Lexikon für Theologie und Kirche 3:242-79.

Mutor, Marek. 2013. "Działalność wrocławskiego biskupa Bolesława Kominka w Rzymie w latach 1960-1972.” In Droga do stabilizacji polskiej administracji kościelnej na Ziemiach Zachodnich i Pótnocnych po II wojnie światowej. W 40. rocznice wydania konstytucji apostolskiej Pawła VI Episcoporum Poloniae coetus, edited by Wojciech Kucharski, 83-99. Wrocław: Ośrodek "Pamięć i Przyszłość".

NowaCKI, Henryk. 1982. Rapporti tra la Chiesa e la communità politica alla luce del $n^{\circ} 76$ della Gaudium et Spes. Disertatio ad lauream in Facultate Iuris Canonici apud Pontificiam Universitatem S. Thomae De Urbe, Roma: Pontificia Università S. Tommaso d'Aquino.

PhILIPS, Gérard. 1966. "Die Geschichte der dogmatischen Konstitution über die Kirche «Lumen Gentium»”. Lexikon für Theologie und Kirche 1:139-55.

Poupard, Paul. 2005. W sercu Watykanu od Jana XXIII do Jana Pawła II. Rozmowa z Marie-Joelle Guillaume. Katowice: Księgarnia św. Jacka.

Rutkowski, Piotr. 2014. Polscy biskupi jako Ojcowie Soboru Watykańskiego II. Warszawa: Wydawnictwo UKSW 2014.

Sitarz, Mirosław. 2013. "Podstawowe zasady relacji Kościół - państwo w nauce społecznej Kościoła." Państwo Prawne 1(3):56-68.

Sitarz, Mirosław. 2015. "Zasada równouprawnienia kościołów i innych związków wyznaniowych." In Katolickie zasady relacji Państwo-Kościót a prawo polskie, edited by Józef Krukowski, Mirosław Sitarz, and Henryk Stawniak, 115-34. Lublin: Towarzystwo Naukowe KUL.

Sitarz, Mirosław. 2016. "Wkład biskupa Walentego Wójcika na rzecz Soboru Watykańskiego II i reformy prawa kanonicznego.” Kościót i Prawo 5(18), no. 2:25-66. Doi: http://dx.doi.org/10.18290/ kip.2016.5.2-3

SkrzyPCZAK, Robert (edited by). 2011. Karol Wojtyła na Soborze Watykańskim II. Zbiór wystapień, trans. Michał T. Szczepański, and Michał Romanek. Warszawa: Centrum Myśli Jana Pawła II, Instytucja Kultury m. st. Warszawa.

SŁowikowska AnNa. 2013. "Origin of principle of cooperation between the Catholic Church and the State in preparatory documents for the Second Vatican Council. Outline." Teka Komisji Prawniczej. Polska Akademia Nauk Oddziat w Lublinie 6:152-68.

SŁowikowska, Anna. 2017. "Podstawy prawne odpowiedzialności wiernych za materialne potrzeby Kościoła.” Kościót i Prawo 6(19), no. 2:123-41. Doi: http://dx.doi.org/10.18290/kip.2017.6.2-10 SobczyK, PAweŁ. 2005. Kościól a wspólnoty polityczne. Warszawa: Wydawca Santiago.

Wenger, Antoine. 1963. Vatican II. L'histoire du Schema XIII. Chronique de la troisième session. Paris: Éditions du Centurion. 
WiLK, Stanisław, and Anna WóJcik (edited by). 2013. Stefan Kardynat Wyszyński Prymas Polski Ojciec Soboru Watykańskiego II 1962-1965. Wybór dokumentów. Lublin: Wydawnictwo KUL 2013. WojTYŁa, Karol. 2002. "Wstęp ogólny.” In Sobór WaTYKaŃsKi II. Konstytucje, dekrety, deklaracje. Polish text, new translation, 9-22. Poznań: Pallottinum.

\section{THE CONTRIBUTION OF BISHOPS OF THE COMMUNIST STATES TO THE TEACHING OF THE SECOND VATICAN COUNCIL WITH RESPECT TO CHURCH-STATE RELATIONS}

\section{Sum mary}

The relations between the Church and the State have always been a delicate and complex issue. Its importance and complexity is reflected by the fact that while the Vatican II was improving and developing its modern doctrine on the ecclesiastical and the political community, no separate document to address this issue was being projected. However, ultimately two such documents were created: the Declaration on Religious Freedom Dignitatis Humanae and the Pastoral Constitution on the Church in the Modern World Gaudium et spes.

The article presents the contribution of bishops from the Communist Bloc states to the teaching of Vatican II regarding Church-State relations. When addressing these relations, the Council limited itself to having speeches and written remarks (animadversiones) delivered only by the bishopsrepresentatives of the Communist Bloc, and this perspective has relevance for the presented study. In those states where a system based on a totalitarian regime was in use, any traces of religious life would be eliminated from social life, and combating the Church was a priory for the state authorities. For this reason, the bishops who exercised their daily ministry in communist countries, were supposed to show to make other bishops aware of the real problems facing the Church, using their own experience. Their involvement and voice were consistent with the assumptions of the Council, which were realised as part of aggiornamento, highlighting the modernisation, revival and adjustment of the Church's activity to changes taking place in the modern world. The outcomes of these bishops' efforts were, among others: the affirmation of human dignity as the source of religious freedom, which was reserved to every human being, the observation that this freedom is our freedom from coercion to do things contrary with our conscience, the highlighting of parents' right to educate their children in the faith, the recognition of the pluralism of world views as well as pluralistic society, which requires a model of its relations with the Church, the consideration of mutual independence of the Church and the political community and the need for cooperation, and the observation that Christians have duties both as Church members and citizens of the State.

Key words: Communism; Church-State Relations; the Second Vatican Council

\section{WKŁAD BISKUPÓW BLOKU PAŃSTW KOMUNISTYCZNYCH W NAUCZANIE SOBORU WATYKAŃSKIEGO II NA TEMAT RELACJI KOŚCIÓŁ- PAŃSTWO}

\section{Streszczenie}

Problematyka relacji Kościół-Państwo zawsze należała do delikatnych i skomplikowanych grup zagadnień. Na ich rangę i złożoność wskazuje chociażby fakt, że podczas pogłębiania i rozwijania współczesnej doktryny o społeczności kościelnej i wspólnocie politycznej przez Sobór Watykański II, 
pierwotnie nie przewidywano oddzielnego dokumentu regulującego to zagadnienie. Jednakże w efekcie umiejscowiono je w dwóch: deklaracji o wolności religijnej Dignitatis humanae i w konstytucji duszpasterskiej o Kościele w świecie współczesnym Gaudium et spes.

W artykule przedstawiony został wkład biskupów bloku państw komunistycznych w nauczanie Vaticanum II na temat relacji Kościół-Państwo. Ograniczenie wypracowywania zasad tych relacji przez Sobór Watykański II do wystąpień i pisemnych uwag (animadversiones) jedynie biskupów-przedstawicieli z bloku Państw komunistycznych jest dla badanego zagadnienia celowe i istotne. W Państwach, w których panował ustrój oparty na reżimie totalitarnym, eliminowano jakiekolwiek pierwiastki religijne z życia społecznego, a walka z Kościołem stanowiła program władz państwowych Dlatego biskupi na co dzień pełniący posługę kościelną w Państwach komunistycznych, dzięki własnemu doświadczeniu, mieli obowiązek unaocznić pozostałym biskupom świata rzeczywiste problemy, z jakimi Kościół powinien się zmierzyć. Swoim zaangażowaniem i głosem wpisali się w założenia Soboru realizowane pod hasłem aggiornamento, wskazując na uwspółcześnienie, odnowienie i dostosowanie działalności Kościoła do zmian, jakie dokonały się we współczesnym świecie. Efektem pracy biskupów z bloku Państw komunistycznych stało się m.in.: wyakcentowanie godności osoby ludzkiej, jako źródła wolności religijnej i przysługiwania wolności religijnej każdemu człowiekowi; określenie, że wolność ta oznacza również wolność człowieka od przymusu do działań sprzecznych z jego sumieniem; podkreślenie prawa rodziców do wychowywania dzieci w wierze; dostrzeżenie pluralizmu światopoglądowego i społeczności pluralistycznej, dla której należy stworzyć model relacji z Kościołem; uwzględnienie wzajemnej niezależności Kościoła i wspólnoty politycznej oraz konieczności ich współdziałania; wskazanie, że chrześcijanie mają swoje obowiązki jako członkowie Kościoła i obywatele Państwa.

Słowa kluczowe: komunizm; relacje Kościół-państwo; Sobór Watykański II 